\title{
Glycoconjugates as target antigens in peripheral neuropathies
}

\author{
Ljubica Suturkova*1, Katerina Brezovska ${ }^{1}$, Ana Poceva-Panovska ${ }^{1}$, \\ Aleksandra Grozdanova ${ }^{1}$, Sladjana Knezevic Apostolski ${ }^{2}$ \\ ${ }^{1}$ University "Ss. Cyril and Methodius", Faculty of Pharmacy, Skopje, Macedonia \\ ${ }^{2}$ Outpatient Neurological Clinic, Belgrade, Serbia
}

Received: October 2014; Accepted: December 2014

\begin{abstract}
Identification and characterization of antigens present at the human peripheral nerve is a great challenge in the field of neuroimmunology. The latest investigations are focused on the understanding of the biology of glycoconjugates present at the peripheral nerve, and their immunological reactivity. Increased titers of antibodies that recognize carbohydrate determinants of glycoconjugates (glycolipids and glycoproteins) are associated with distinct neuropathic syndromes. There is considerable cross-reactivity among anti-ganglioside antibodies, resulting from shared oligosaccharide epitopes, possibly explaining the overlap in syndromes observed in many affected patients. Sera from patients with neuropathies (GBS, chronic inflammatory demielynating polyneuropathy - CIDP, multifocal motor neuropathy - MMN), cross-react with glycoproteins isolated from human peripheral nerve and from Campylobacter jejuni O:19. The frequency of occurrence of antibodies against these glycoproteins is different, depending of the type of neuropathy. Identification of the cross-reactive glycoproteins and possible additional auto antigens could be useful in laboratory evaluation of peripheral neuropathies and help to develop a more effective therapeutic approach.
\end{abstract}

Key words: glycoproteins, gangliosides, cross-reactivity, neuropathies, Campylobacter jejuni

\section{Autoimmune neuropathies}

Autoimmune neuropathies are described by presence of symptoms of weakness, sensory loss and autonomic dysfunctions as a consequence of immune mediated damage of peripheral nerve. Autoimmune neuropathies are heterogeneous in clinical presentation and mechanism of development (Asbury, 1994). From the clinical point of view, autoimmune neuropathies may have acute onset and monophasic course (Guillian-Barré syndrome - GBS and its variants), or chronic slow progressive or relapsing clinical course (chronic inflammatory demyelinating poliradiculoneuropathy - CIDP, and Multifocal motor neuropathy -

* tel. +38923126032 ; fax. +38923123054

ljsu@ff.ukim.edu.mk
MMN) with different pathological and electrophysiological features (Griffin and Sheikh, 2005).

Guillian-Barré syndrome (GBS) is an acute monophasic inflammatory neuropathy, which can be classified in several variants according to pathological changes and electrophysiological findings. The histologic features of the GBS support a classification into demyelinating and axonal forms. The subtypes of GBS are acute inflammatory demyelinating polyneuropathy (AIDP), acute motor axonal neuropathy (AMAN) and Miller Fisher syndrome (MFS). AIDP is characterized by primary demyelination, while AMAN is characterized by primary axonal degeneration of the peripheral nerves developed trough noninflammatory complement dependent mechanism mediated by antibodies (Asbury et al., 1969; McKhann et al., 1993, Grif- 
fin et al., 1996, Hafer-Macko et al., 1996). MFS is characterized by an acute onset of ataxia, areflexia and ophtalmoplegia (Fisher 1956). All of these GBS variants have CSF finding characterized by increased protein level and normal cell count (albumino-cytological dissociation) and may have a detectable spectrum of serum antiganglioside antibodies. The molecular mimicry is the basic immune mechanism involved in the onset of the disease. Antibodies induced by the primary infective agent recognize the peripheral nerve antigens and consequentially activate cell-mediated autoimmune response (Kuwabara et.al., 2002, Willison and Yuki, 2002, Yuki and Hartung, 2012).

Chronic inflammatory demielynating neuropathy (CIDP) is well defined demyelinating autoimmune polyneuropathy with relapse-remittent course of the disease and a good therapeutic response to corticosteroids. CIDP is accompanied with the presence of a number of different antibodies to the constituents of the peripheral nerve, which explains the good response of the plasma exchange in these patients. The presence of the antiganglioside antibodies in sera from patients with CIDP is also very important (Willison and Yuki N, 2002).

Multifocal Motor Neuropathy (MMN) is a chronic immune mediated neuropathy characterized by asymmetric, predominantly distal upper limb weakness without sensory impairment and by the presence of multifocal persistent partial conduction blocks on motor but not on sensory nerves (Nobile-Orazio, 2001). The muscle weakness related to individual motor nerve is associated with motor conduction block, at site distinct from common entrapment or compression syndromes (Ghosh et al., 2005; van der Meché et al., 1995; Willison and Yuki, 2002).

\section{Peripheral nerve antigens in autoimmune neuropathies}

Increased titer of antibodies that react with human peripheral nerve antigens are detected in patients with immune-mediated neuropathies (Quarles et al., 1990, Latov, 1994, O’Leary and Willison, 2000). Identification and characterization of auto-antigens present at the human peripheral nerve represents a great challenge in the field of neuroimmunology, especially in demyelinating disorders. Analysis of the molecular composition of human peripheral nerve showed presence of highly complex and organized structure including different glycoprotein and glycolipid molecules, which can be targeted by auto antibodies in inflammatory processes (Willison and Yuki, 2002).

There are a number of studies indicating that myelinspecific proteins present in peripheral nervous system are implicated in autoimmune neurological diseases including autoimmune peripheral neuropathies. These include myelin proteins myelin protein zero (P0), myelin -associated glycoprotein (MAG), peripheral myelin protein 2 (P2), peripheral myelin protein 22 (PMP22) and other myelin specific proteins that have an important role in myelin formation and in mediating autoimmune peripheral nerve disease (Quarles 1989, Hughes and Cornblath, 2005, Khalili-Shirazi et al., 1993, Quarles et al., 1990, Gabriel et al., 2000, Allen et al., 2005). Recent studies are focused on a wide range of proteins that play a crucial role in the formation of the nodes of Ranvier, localized on the nodal complex, including neurofascin, gliomedin and contactin, which are considered as potential antigens for participation in the pathological process of GBS and CIDP (Devaux et al., 2012, Devaux, 2012, Ng et al., 2012, Hughes and Willison, 2012).

Neural glycolipids, including galactocerebrosides and gangliosides (LM1, GM1, GD1A and GQ1b) are another important category of peripheral nerve antigens, which might participate in the immunological targeting that results in neural inflammation (Asbury, 1994, Latov, 1994, Willison and Yuki, 2002).

Antibodies to a wide range of glycolipids including GM1, GD1A, GalNAc-GD1A GM1, GD3, GalC, LM1, SGPG ,GQ1b, GT1a and to peripheral nerve proteins have been reported in more than a 200 papers on GBS and other inflammatory neuropathies as a case studies and in larger series (Table 1). The epidemiological patterns of anti-ganglioside antibodies vary substantially between geograph-

Table 1. Peripheral nerve antigens associated with autoimmune neuropathies

\begin{tabular}{lcl}
\hline \hline \multicolumn{1}{c}{ Clinical syndrome } & $\begin{array}{c}\text { Antibody } \\
\text { type }\end{array}$ & \multicolumn{1}{c}{ Antigen } \\
\hline $\begin{array}{l}\text { Guillain-Barré syndrome } \\
\text { AMAN }\end{array}$ & & $\begin{array}{l}\text { GM1, GD1A, GalNAc-GD1A } \\
\text { GM1, GalC, LM1, SGPG } \\
\text { GQ1b, GT1a }\end{array}$ \\
$\begin{array}{l}\text { AIDP } \\
\text { MFS }\end{array}$ & IgG & $\begin{array}{l}\text { PO, P2, MAG, PMP 22, } \\
\beta \text {-tubulin, Conexin 32, gliomedin, con- } \\
\text { tactin, neurofascin }\end{array}$ \\
$\begin{array}{l}\text { Chronic inflammatory demyelinating polira- } \\
\text { diculoneuropathy }\end{array}$ & IgM & $\begin{array}{l}\text { GM1, GD1a, GM2 } \\
\text { (CIDP) }\end{array}$ \\
$\begin{array}{l}\text { Multifocal motor neuropathy (MMN) } \\
\text { IgG, IgM }\end{array}$ & $\begin{array}{l}\text { PO, P2, MAG, PMP 22, } \\
\beta-\text {-tubulin, Conexin 32, neurofascin }\end{array}$ \\
\hline
\end{tabular}


ic regions, according to the prevalent subtypes of GBS and their relationship to preceding infections, such as Campylobacter jejuni (C. jejuni) infection (Azhary et al., 2010).

Increased titers of antibodies against GM1 ganglioside are found in patients with motor neuropathies. AntiGM1 antibodies can be of different isotype, IgM antibodies are associated with MMN, whereas IgG antibodies are typical for acute onset neuropathies, or variants of GBS (Latov, 1990, Pestronk and Choski, 1997). Anti GM1 antibodies of IgG type are characteristic feature of AMAN, but a proportionof of patients with AIDP have also these antibodies (Willison and Yuki, 2002, Yuki and Hartung, 2012). Over $90 \%$ of patients with MFS have elevated titers of antiGQ1b antibodies, indicating the role of the anti-ganglioside antibodies in the disease (Yuki et al., 2000). Increased antibody titers against multiple gangliosides have been reported in multifocal acquired sensory and motor neuropathy, possibly implicating immune mechanisms in their pathogenesis. IgM anti-GM1 antibodies are associated with multifocal motor neuropathy (MMN). Up to $80 \%$ of the patients with MMN may have anti-GM1 antibodies. The antibodies are most often polyclonal, but can also occur as IgM monoclonal gammopathies. Most of the antibodies bind to the Gal(beta1-3)GalNAc epitope, shared by asialoGM1 and GD1, but some bind to GM1 alone, or to GM1 and GM2. This syndrome, MMN, has a stronger association with the occurrence of antiganglioside antibodies, especially against GM1, compared to GBS and CIDP (Cats et al., 2010, van der Meché et al., 1995, Willison and Yuki, 2002).

Autoantibodies, against myelin proteins P2, P0, Myelin associated glycoprotein, PMP22, $\beta$-tubulin and Conexin 32, mostly of IgG isotype, are detected in sera from patients with GBS and chronic demyelinating neuropathies, including CIDP (Khalili-Shirazi et al., 1993, Quarles et al., 1990, Gabriel et al., 1999, Allen et al., 2005). Also IgG antibodies directed to neurofascin, gliomedin, and contactin are also detected in sera from patients with GBS and CIDP and were associated with demyelination and conduction loss in experimental model (Devaux et al., 2012, Devaux, 2012, $\mathrm{Ng}$ et al., 2012, Hughes and Willison, 2012).

There is considerable cross reactivity among anti-glycoconjugate antibodies, resulting from shared oligosaccharide epitopes, possibly explaining the overlap in syndromes observed in many affected patients (Latov, 1994). Antiganglioside antibodies in sera from patients with GBS recognize galactosyl ( $\beta 1-3) \mathrm{N}$-acetylgalactosamine $(\mathrm{Gal}(\beta 1-3)$ GalNAc) epitope, a carbohydrate determinant shared by several gangliosides (GM1, GD1a, GD1b, GT1b and asialo ganglioside GA1), several peripheral nerve glycoproteins and several antigens present in bacterial cell wall (Thomas et al., 1989, Aspinall et al., 1994).

\section{Molecular mimicry}

The current investigations are based on hypothesis of ganglioside mimicry of $C$. jejuni lipopolysaccharides in
GBS together with the pathogenic role of different antibodies which interfere with nerve conduction or induce damage of the nerves. There are experimental evidence based on research on animal models and human about the molecular mimicry between gangliosides and lipooligosaccharide (LOS) from $C$. jejuni. The bacteria isolated from GBS patients have LOS, which structure resembles GM1 or GD1a gangliosides, whereas isolates from patients with Miller Fisher syndrome, have LOS with structure similar to GQ1b (Yuki et al., 1993, Koga et al., 2005). Antibodies that cross-react with LOS from $C$. jejuni and with different gangliosides from peripheral nerves are detected in sera from patients with GBS following infection with $C$. jejuni (Wirguin et al., 1994).

Serotype of $C$. jejuni which is the most frequently associated with developing of GBS is Penner's serotype O:19, which has (LOS), with structure similar to the structure of oligosaccharides present in GM1 and asialo-GM1gangliosides (Yuki et al., 1990, Walsh et al., 1991, Fujimoto et al., 1992). The Penner's O:19 serotype of C. jejuni contains LOS with GM1 - like oligosaccharides-determinants and is most commonly associated with pure motor GBS (Fujimoto et al., 1992, Yuki et al., 1995).

Although ganglioside mimicry associated with the production of anti-ganglioside antibodies accelerates the symptoms of GBS, the pathogenesis of this disease remains unclear. A number of patients with enteritis caused by $C$. jejuni, which contain LOS with structure similar to human gangliosides, do not develop neurological symptoms, indicating that only the presence of these structures is not sufficient to induce production of antiganglioside antibodies. The data that the most of $C$. jejuni infections caused by the serotypes containing ganglioside-like LOS, do not result in GBS, indicate that other host related and/ or bacterium related factors contribute in the development of neurological symptoms after an infection with $C$. jejuni, but these factors still remain unknown (Willison and Yuki, 2002, Karlyshev et al., 2005). The possible factor could be the influence of other host related factors such as polymorphism in immune response genes, in addition to bacterium related factors, in the development of neurological symptoms after an infection with $C$. jejuni. This may either depend on differential expression of ganglioside mimics in $C$. jejuni LOS, due to phase variation in genes encoding glycosyltransferases, or to the influence of other immunomodulating factors (Ang et al., 2002).

The role of antibodies to the peripheral nerve myelin proteins and glycoproteins was not sufficiently investigated in GBS (Gabriel et al., 2000). Sera from patients with GBS showed immunological reactivity to $70 \mathrm{kDa}, 50$ $60 \mathrm{kDa}, 40,35$ and $30 \mathrm{kDa}$ protein isolated from C. jeju$n i$ (Kaldor and Speed, 1984). GM1-positive sera from patients with GBS following infection with $C$. jejuni showed reactivity to a $63-\mathrm{kDa}$ flagellar protein purified from $C$. jejuni (O:19) (Lange et al., 1999). It has also been shown that GM1 antibodies cross-react with Gal-GalNAc-bearing 
glycoproteins from the peripheral nerve (Apostolski et al., 1994). Cross-reactive determinants were detected in glycoproteins from human peripheral nerve and C. jejuni O:19, recognized by peanut agglutinin (PNA) and by GM1 positive sera from patient with GBS associated with C. jeju$n i$ infection. Results from our research group showed positive cross-reactivity of the peptides from the human peripheral nerve and $C$. jejuni recognized by GM1-positive GBS serum associated with $C$. jejuni infection (Brezovska et al., 2011, Poceva Panovska et al., 2011). Results of our study revealed structural similarity in oligosaccharide portion and immunoreactivity of the glycoproteins isolated from peripheral nerve and C. jejuni, indicating that they are potentially cross-reactive determinants and may contribute to the development of GBS associated with antecedent $C$. jejuni infection (Poceva-Panovska et al., 2011).

There are literature data for the reactivity of anti-GM1 and asialo-GM1 antibodies from patients with MMN or chronic neuropathies with the LOS of $C$. jejuni (Wirguin et al., 1994). The possibility that $C$. jejuni may also be involved in the pathogenesis of MMN has supported by several reports of patients developing MMN and high titers of anti-GM1 antibodies after C. jejuni enteritis (White et al., 1996, Abbruzzese et al., 1997, Taylor et al., 1998, Terenghi, et al., 2002).

In our research we have shown the cross-reactivity of GM1 positive sera from patients with MMN and GM1-like protein antigens isolated from human peripheral nerve and from C. jejuni O:19. Higher IgG anti-GM1 frequency was found in patients with GBS (36.4\%). In other groups, IgG anti-GM1 antibodies were present in patients with CIDP (6.7\%) and in patients with MMN. Patients with MMN represented a group with the highest IgM anti-GM1 reactivity $(45.8 \%)$. Higher frequency of the presence of anti-ganglioside and anti-glycoprotein antigens in patients with MMN compared to healthy controls and to patients with other neuropathies point out their pathogenic significance in the inducing and propagation of the nerve damage and development of neurological symptoms (Suturkova et al., 2013).

The cross-reactivity of antibodies from tested sera to human peripheral nerve antigens and antigens isolated from $C$. jejuni, could be explained by the concept of natural auto antibodies, reflecting the natural non-pathogenic autoimmunity or by the presence of antibodies generated from infections and natural exposure to pathogens, including C. jejuni (Avrameas, 1991, Panigrahi et al., 1992, Gabriel et al., 2000).

The increased titer of antibodies to human peripheral nerve antigens in patients with neuropathies, could be explained as a secondary reaction to the exposure of nonimmunogenic nerve antigens, following demyelination and nerve cell damage (Gabriel et al., 2000). These autoantibodies may further contribute to the progression and deterioration of the disease.

The higher frequency of the presence of anti-ganglioside and anti-glycoprotein antigens in patients with GBS, CIDP and MMN, compared to healthy controls and to pa- tients with other neuropathies point out their pathogenic significance in the inducing and propagation of the nerve damage and development of neurological symptoms. The cross-reactivity of these antibodies to $C$. jejuni antigens, indicate on the shared epitopes between human and bacterial glycoproteins, and their possible role in the induction of autoantibodies and peripheral neuropathies following infection with $C$. jejuni. Determination of the structure and localization of the cross-reactive PNA-binding glycoproteins will help in understanding the mechanisms that trigger myelin-related neurological diseases.

\section{Conclusions}

The cross-reactivity of anti-glycolipid and anti-glycoprotein antibodies to $C$. jejuni antigens, indicate on the shared epitopes between human and bacterial glycoproteins, and their possible role in the induction of autoantibodies and peripheral neuropathies following infection with C. jejuni. These cross-reactive glycoproteins, together with GM1 ganglioside are potentional antigens for autoantibodies, and may play a significant role in the development of autoimmune peripheral neuropathies. These findings provide a new concept in the antibody-antigen interactions based on carbohydrate epitopes structure. Studies using autoimmune neuropathy sera may continue to identify additional glycosphingolipids and glycoproteins that have yet to be identified as autoantigens, these will be aided by further development of purification and analysis methods. The findings will be useful in laboratory evaluation of peripheral neuropathies and help to develop a more effective therapeutic approach.

Resolving the mechanisms which regulate the B cells to produce anti glycoconjugate antibodies in patients with neuropathies, will give an opportunity to develop specific and effective strategy for targeted immunotherapy in order to prevent or limit the processes that result in autoimmune neuropathy. The other important issue is genetic factor from bacteria and host involved in the immune response of peripheral neuropathies. Still the research of the genetic factors is under intensive investigation. Maybe in the future testing of the polymorphism will be part of laboratory evaluation of peripheral neuropathies.

\section{References}

Abbruzzese, M., Reni, L., Schenone, A., Mancardi, G.L., Primavera, A. 1997. Multifocal motor neuropathy with conduction block after Campylobacter jejuni enteritis. Neurology. 48, (2), 544. Letter.

Allen, D., Giannnopoulos, K., Gray, I, Gregson, N., Makowska, A., Pritchard, J., Hughes, R.A.C., 2005. Antibodies to peripheral nerve myelin proteins in chronic inflammatory demyelinating polyradiculoneuropathy, J. Periph. Nerve. Sys, 10, 174-180.

Ang, C.W., Laman, J.D., Willison, H.J., Wagner, E.R., Endtz, H.P., 
De Klerk, M.A., Tio-Gillen, A.P., Van den Braak, N., Jacobs, B.C., Van Doorn, P.A. 2001. Structure of Campylobacter jejuni lipopolisaccharides determines antiganglioside specificity and clinical features of Guillain-Barre and Miller Fisher patients, Infect.Immun. 70, 1202-1208.

Apostolski, S., Sadiq, S.A., Hays, A., Corbo, M., SuturkovaMislosevic, Lj., Chaliff, P., Stefansson, K., LeBaron, R.G., Ruoslahti, E., Hays, A.P., Latov N, 1994. Identification of Gal ( $\beta 1-3)$ GalNAc bearing glycoproteins at the nodes of Ranvier in peripheral nerve. J Neurosci Res. 38, 134-41.

Asburi, A.K., 1994. Gangliosides and peripheral neuropathies: an overview, in: Svennerholm, L., Asbury, A.K., Reisfeld, R.A., Sandoff, K., Suzuki K., Tettamanti G, Toffano G, (Eds), Progress in brain research, Biological function of gangliosides, Elsvier Amsterdam-London-New York-Tokyo, Vol. 101, 279 - 287.

Asbury, A.K., Arnason, B.G., Adams, R.D. 1969. The inflammatory lesion in idiopathic polyneuritis: its role in pathogenesis. Medicine (Baltimore). 48, 173-215.

Aspinall, G.O., Armando, G., McDonald, A.G., Pang, H., 1994. Lipopolysachharides of Campylobacter jejuni serotype O:19: Structures of $O$ antigen chains from the serostrain and two bacterial isolates from patients with Guillain-Barre syndrome, Biochemistry, 33, 250-255.

Avrameas, S., 1991. Natural autoantibodies: from 'horror autotoxicus' to 'gnothi seauton', Immunol. Today, 12 (5), 154-159.

Azhary, H., Farooq, M. U., Bhanushali, M., Majid A., Kassab M. Y., 2010. Peripheral Neuropathy: Differential Diagnosis and Management, American Family Physician 81, (7), 887- 892.

Brezovska, K., Poceva Panovska, A., Grozdanova, A., Suturkova, Lj., Basta, I., Apostolski, S. 2011. Immunoreactivity of glycoproteins isolated from human peripheral nerve and Campylobacter jejuni (O:19), J. Neurosc.Rural Pract. 2,(2), 125-129.

Cats, E.A., Jacobs, B. C., Yuki, N., Tio-Gillen, A.P., Piepers, S., H. Franssen, van Asseldonk, J.T., van den Berg, L.H., van der Pol. W. L., 2010. Multifocalmotor neuropathy: association of anti-GM1 IgM antibodies with clinical features, Neurology, 75, (22), 1961-1967.

Devaux, J.J., 2012. Antibodies to gliomedin cause peripheral demyelinating neuropathy and the dismantling of the nodes of Ranvier, Am. J. Pathol. 181 (4) 1402-1413.

Devaux, J.J., Odaka, M., Yuki, N., 2012. Nodal proteins are target antigens in Guillain-Barré syndrome, J Peripher Nerv Syst. $17(1), 62-71$.

Fisher, M., 1956. An unusual variant of acute idiopathic polyneuritis (syndrome of ophtalmoplegia, ataxia and areflexia). N. Engl. J. Med. 255, 57-65.

Fujimoto, S., Yuki, N., Itoh, T., Amako. K., 1992. Specific serotype of Campylobacter jejuni associated with GuillainBarré syndrome. J. Infect. Dis., 165, (1),183 (Letter).

Gabriel, C.M., Gregson, N.A., Hughes, R.A.C., 2000. AntiPMP22 antibodies in patients with inflammatory neuropathy, J. Neuroimmunol., 104: 139-146.

Ghosh, A., Busby, M., Kennett, R., Mills, K., Donaghy, M.A. 2005. A practical definition of conduction block in IVIg responsive multifocal motor neuropathy, J. Neurol. Neurosurg. Psychuatry, 76, (9), 1269-1272.

Griffin, J.W, Li, C.Y., Macko, C., Ho, T.W., Hsieh, S.T., Xue, P., Wang, F.A., Cornblath, D.R., McKhann, G.M., Asbury, A.K., 1996. Early nodal changes in the acute motor axonal neuropathy pattern of the Guillain-Barré syndrome. J.
Neurocytol., 25, 33-51.

Griffin, J.W., Sheikh, K., 2005, The Guillain-Barré syndromes, in Dyck PJ and Thomas PK (Eds) Peripheral neuropathy, Philadelphia: Elsvier Saunders, vol 2, 2197-2220.

Hafer-Macko, C, Hsieh, S.T., Li,C.Y., Ho, T.W., Sheikh, K, Cornblath, D,R, McKhann, G.M., Asbury AK, Griffin JW, 1996. Acute motor axonal neuropathy: an antibodymediated attack on axolemma, Ann Neurol, 40, 635-644.

Hughes, R.A.C., Willison, H.J., 2012. Neurofascin antibodies in inflammatory Neuropathy, How many needles make a haystack? Neurology. 79,1-2.

Hughes, R.A.C., Cornblath, D.R., 2005. Guillian-Barré syndrome, Lancet, 266, 1653-1666.

Kaldor, J., Speed, B.R,, 1984. Guillain-Barré syndrome and Campylobacter jejuni: a serological study, Br. Med. J. (Clin. Res. Ed.), 23; 288 (6434):1867-1870.

Karlyshev, A.V., Champion, O.L., Churcher, C., Brisson, J.R., Jarrell, H.C., Gilbert, M., Brochu, D., St Michael, F., Li, J., Wakarchuk, W.W., Goodhead, I., Sanders, M., Stevens, K., White, B., Parkhill, J., Wren, B.W., Szymanski, C.M., 2005. Analysis of Campylobacter jejuni capsular loci reveals multiple mechanisms for the generation of structural diversity and the ability to form complexheptoses, Mol. Microbiol. 55, 90-103.

Khalili-Shirazi, A., Atkinson, P., Gregson, N., Hughes, R.A.C., 1993. Antibody responses to P0 and P2 myelin proteins in Guillain-Barré syndrome and chronic idiopathic demyelinating polyradiculoneuropathy, J. Neuroimmunol. 46 (1-2), 245-251.

Koga, M., Gilbert, M., Li, J., Koike, S., Takahashi, M., Furukawa, K., Hirata, K., Yuki, N., 2005. Antecedent infections in Fisher syndrome: a common pathogenesis of molecular mimicry, Neurology, 64, 1605-1611.

Kuwabara, S., Ogawara, K., Sung, J.Y., 2002. Differences in membrane properties of axonal and demyelinating GuillainBarré syndromes. Ann.Neurol. 52, 180-187.

Lange, D., Aleksic, S., Kassubek, J., Vrvic, M.M., Kist, M., Steinbruckner, B., Mitova, M., 1999. Detection of antibodies against Campylobacter jejuni serogroup PEN O:19 purified flagellar protein in a patient with Guillain-Barré syndrome, Zent. B1. Bakteriol. 289, 429-444.

Latov, N., 1990. Neuropathy and anti-GM1 antibodies, Ann. Neurol. 27 Suppl. S41-43.

Latov, N., 1994. Antibodies to glycoconjugates in neuropathiy and motor neuron disease in: Svennerholm L, Asbury AK, Reisfeld RA, Sandoff K, Suzuki K, Tettamanti G, Toffano $\mathrm{G}$, (Eds), Progress in brain research, Biological function of gangliosides, Elsvier Amsterdam-London-New York-Tokyo, Vol. 101, 295-303.

McKhann, G.M., Cornblath, D.R., Griffin, J.W., Ho, T.W., Li, C.Y., Jiang, Z., Wu, H.S., Zhaori, G., Liu, Y., Jou, L.P. et al. 1993. Acute motor axonal neuropathy:a frequent cause of acute flaccid paralysis in China, Ann Neurol. 33, 333-342.

Ng, J. K., Malotka, J., Kawakami, N., Derfuss, T., Khademi, M., Olsson, T., Linington, C., Odaka, M., Tackenberg, B., Prüss, H., Schwab, J.M., Harms, L., Harms, H., Sommer, C., Rasband, M.N., Eshed-Eisenbach, Y., Peles, E., Hohlfeld, R., Yuki, N., Dornmair, K., Meinl, E. 2012. Neurofascin as a target for autoantibodies in peripheral neuropathies Neurology, 79 (23), 2241-2248.

Nobile-Orazio, E., 2001. Multifocal motor neuropathy. J. Neuroimmunol. 115, (1-2), 4-18.

O'Leary, C.P., Willison, H.J. 2000. The role of antiglycolipid

Макед. фарм. билт., 60 (2) 21 - 27 (2014) 
antibodies in peripheral neuropathies. Curr Opin Neurol. 13, 583-588.

Panigrahi, P., Losonsky, G., DeTolla, L.J., Jr Morris, J.G., 1992. Human immune response to Campylobacter jejuni proteins expressed in vivo, Infect. Immun., 60(11), 4938-4944.

Pestronk, A., Choksi, R. 1997. Multifocal motor neuropathy. Serum IgM anti GM1 ganglioside antibodies in most patients detected using covalent linkeage of GM1 to ELISA plates, Neurology, 49, 1289-1292.

Poceva-Panovska, A., Brezovska, K., Grozdanova, A., Apostolski, S., Suturkova, Lj., 2011. Immunoreactivity and characterization of oligosaccharide determinants in glycoproteins isolated from peripheral nerve and Campylobacter jejuni O:19, Neurol.Croat. 60 (2), 61-68.

Quarles RH, 1989. Glycoproteins of Myelin and Myelin forming cells, in: Richard U. Margolis and Renée K. Margolis, (Eds) Neurobiology of glycoconjugates, Plenum press, New York, 243-276.

Quarles, R.H., Llyas, A.A., Willison, H.J., 1990. Antibodies to gangliosides and myelin proteins in Guillain-Barré syndrome, Ann. Neurol. 27, S48-52.

Suturkova, Lj., Brezovska, K. Poceva-Panovska, A., Grozdanova, A., Knezevic Apostolski, S., Basta I., 2013. Antibodies to Glycoproteins Shared by Human Peripheral Nerve and Campylobacter jejuni in Patients with Multifocal Motor Neuropathy, Autoimmune Diseases Volume 2013.

Taylor, B.V., Phillips, B.A., Speed, B.R., Kaldor, J., Carroll, W.M., Mastaglia, F.L., 1998. Serological evidence for infection with Campylobacter jejuni/coli in patients with mltifocal motor neuropathy, J. Clin. Neurosci. 5, (1), 33-35.

Terenghi, F., Allaria, S., Scarlato, G., Nobile-Orazio, E., 2002. Multifocal motor neuropathy and Campylobacter jejuni reactivity, Neurology, 59, (2), 282-284.

Thomas, F.P., Lee, A.M., Romas, S.N., Latov, N., 1989. Monoclonal IgMs with anti-Gal( $\beta 1-3)$ GalNAc activity in lower motor neuron disease: identification of glycoprotein antigens in neural tissue and cross reactivity with serum immunoglobulins, J. Neuroimmunol. 23,167-174.

van der Meché, F.G., van Doorn, P.A., Jacobs, B.C., 1995. Inflammatory neuropathies: pathogenesis and the role of intravenous immune globulin, J. Clin. Immunol. 15 (6 Suppl):63S-69S.

Walsh, F.S., Cronin, M., Koblar, S., Doherty, P., Winer, J., Leon, A., Hughes, R.A., 1991. Association between glycoconjugate antibodies and Campylobacter infection in patients with Guillain-Barré syndrome J. Neuroimmunol., 34, (1), 43-51.

White, J.R., Sachs, G.M., Gilchrist, J.M., 1996. Multifocal motor neuropathy with conduction block and Campylobacter jejuni. Neurology. 46, (2), 562-563.

Willison, H.J., Yuki, N., 2002. Peripheral neuropathies and antiglycolipid antibodies, Brain. 125, 2591-2625.

Wirguin, I., Suturkova-Milosevic, Lj., Della-Latta, P., Fisher, T., Brown, R.H.Jr., Latov, N. 1994. Monoclonal IgM antibodies to GM1 and asialo GM1 in chronic neuropathies crossreact with Campylobacter jejuni lipopolysaccharides, Ann. Neurol, 35, (6), 698-703.

Yuki, N., Yoshino, H., Sato, S., Miyatake, T., 1990. Acute axonal polyneuropathy associated with anti-GM1 antibodies following Campylobacter enteritis, Neurology. 40, 19001902.

Yuki, N., Handa, S., Tai, T., Takahashi, M., Saito, K., Tsujino, Y., Taki, T., 1995. Ganglioside-like epitopes of lipopolysaccharides from Campylobacter jejuni (PEN 19) in three isolates from patients with Guillain-Barré syndrome, $\mathrm{J}$ Neurol Sci. 130(1), 112-116.

Yuki, N., Hartung, H.P., 2012. Guillain-Barré syndrome. N Engl J Med. 14,366(24),2294-2304.

Yuki, N., Susuki, K., Hirata, K., 2000. Ataxic Guillain-Barré syndrome with anti GQ1b antibody, relation to miller-Fisher syndrome, Neurology. 54, 1851-1853.

\title{
Гликонјугати како целни антигени во периферните невроаптии
}

\author{
Љубица Шутуркова*1, Катерина Брезовска ${ }^{1}$, Ана Поцева-Пановска ${ }^{1}$, \\ Александра Грозданова ${ }^{1}$ Слаѓана Кнежевиќ Апостолски²

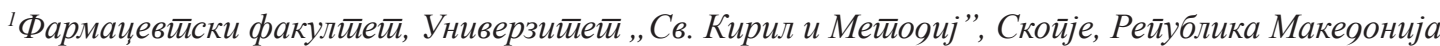 \\ ${ }^{2}$ Outpatient Neurological Clinic, Belgrade, Serbia
}

Клучни зборови: гликопротеини, ганглиозиди, вкрстена-реактивност невропатии, Campylobacter jejuni

Идентификацијата и карактеризацијата на автоантигените присутни во периферниот нервен систем на човекот, претставува голем предизвик во полето на клиничката невроимунологија. Најновите истражувања се насочени кон разбирањето на биологијата на гликоконјугатите присутни во периферните нерви и нивната имунолошка реактивност. Зголемен титар на антитела кои ја препознаваат јаглехидратната детерминанта на гликонјугатите (гликолипиди и гликопротеини) се поврзани со ралични невропатски синдроми. Утврдена е значителна вкрстена реактивност помеѓу 
антиганглиозидните антитела, како резултат на постоење на заеднички епитопи, што претставува една од можните причини за постоење на заеднички симптоми кај пациентите со невропатии. Серуми одпациенти со невропатии (Guillain - Barré синдром, хронична инфламаторна демиелинизирачка полиневропатија, мултифокална моторна невроаптија) покажуваат имунолошка реактивност со протеини изолирани од хуман периферен нерв и од Campylobacter jejuni O:19. Фреквенцијата на појава на антителата насочени кон овие гликопротеини е различна во зависност од типот на невропатијата. Идентификацијата на овие вкрстено реактивни антигени, или други потенцијални антигени, може да помогне во разбирањето на етиологијата на периферните невропатии, како и во лабораториската евалуација на периферните невропатии и развивањето на поефикасни терапевтски пристапи. 
